\title{
OS FUNDAMENTOS RELIGIOSOS DO IDEAL DE MERCADO PERFEITO EM ADAM SMITH ${ }^{1}$ \\ RELIGIOUS FOUNDATION OF THE IDEAL OF PERFECT MARKET IN ADAM \\ SMITH
}

DOI: $10.5533 / 1984-2503-20102306$

Ricardo G. Borrmann

\section{RESUMO}

Este artigo visa descortinar os fundamentos religiosos do ideal de mercado perfeito na economia política de Adam Smith, demonstrando como suas premissas básicas têm raízes na teologia medieval. Por meio de um enfoque que privilegia a história das idéias políticas, deseja-se também desconstruir a fácil oposição entre razão/ciência e religião, mostrando o quanto a moderna idéia de ciência está marcada pela cultura religiosa.

Palavras-chave: Economia Política, mercado perfeito, teologia medieval, história das idéias políticas, cultura religiosa.

\section{RESUMEN}

Ese artículo tiene como objetivo distinguir las bases religiosas del mercado perfecto en la economía política de Adam Smith, demonstrando como sus premisas básicas tienen raíces en la teología medieval. Por medio de un enfoque que privilegia la historia de las ideas políticas, uno desea desconstruir la oposición fácil entre razón/ciencia y religión, mostrando quanto la moderna idea de ciencia está marcada por la cultura religiosa.

Palabras-clave: Economía Política, mercado perfecto, teología medieval, historia de las ideas políticas, cultura religiosa.

\footnotetext{
${ }^{1}$ O presente artigo desenvolve argumentos apresentados na dissertação de mestrado "Tal Mercado, Tal Príncipe: o paradigma da perfeição na economia política burguesa", orientada pelo Prof. Titular de Teoria Política Dr. Gisálio Cerqueira Filho no Programa de Pós-Graduação em Ciência Política da Universidade Federal Fluminense (PPGCP/UFF).
} 


\section{ABSTRACT}

This article aims to unfold the religious basis of the perfect market ideal in the political economy of Adam Smith, demonstrating how its basic premises have roots in the medieval theology. Through an approach that emphasizes the history of political ideas, one wishes to deconstruct the easy opposition between reason/science and religion, showing how much modern idea of science is marked by religious culture.

Key-words: Political Economy, perfect market, medieval theology, history of political ideas, religious culture.

\section{RÉSUMÉ}

Ce article veut distinguer les fondements religieux d'ideal de marché parfait presents dans l'économie politique d'Adam Smith, en demontrant comme ses principes basiques ont des racines à la théologie médiévale. A travers d'une perspective qui privilégie l'histoire des idées politiques, on désire deconstruire la facile opposition entre raison/science e religion, en montrant combien la moderne idée de science est marquée par la culture religieuse.

Mots-clés: Économie Politique, marché parfait, théologie médiévale, histoire des idées politiques, culture religieuse.

Adam Smith é quase unanimemente considerado o pai da economia política, tendo influenciado profundamente todo o seu desdobramento posterior. Esta, por sua vez, deu origem àquilo que hoje conhecemos simplesmente como "economia" ou "ciências econômicas". Entretanto, a influência das ideias de Adam Smith se estende especialmente ao campo do liberalismo econômico. Isso porque a principal criação teórica de sua obra-magna, "A Riqueza das Nações", foi o mercado autorregulável, fundamento básico da teoria econômica liberal e imagem por excelência de uma suposta "realidade econômica" sui generis². Nessa obra, os "fenômenos econômicos" teriam sido abordados de acordo com os fundamentos da "ciência moderna". Adam Smith seria então considerado responsável por dotar os estudos econômicos de

\footnotetext{
${ }^{2} \mathrm{O}$ argumento do "mercado" enquanto imagem por excelência de uma suposta "realidade econômica" está desenvolvido em Duarte, Valter (1997). "Sistema de mercado': o ideal político e religioso de Adam Smith". In: Economia: Obstáculo Epistemológico. Tese de Doutorado. Instituto de Economia Industrial, UFRJ, Rio de Janeiro, p. 359-391.
} 
"racionalidade", emprestando a esse campo do saber autonomia e cientificidade, secularizando-o conseqüentemente.

O presente artigo visa justamente desmitificar esse ideal de uma "razão secular" na obra de Adam Smith, como via para se atingir uma suposta "cientificidade". Nesse sentido, pretendemos demonstrar, ao contrário do que comumente se pensa, como é frágil a oposição entre secularização/cientificidade e religiosidade, desconstruindo a ideia de que em Adam Smith a cultura religiosa não tem nenhuma importância ou constitui um aspecto de menor monta. Muito pelo contrário, a religiosidade é um componente imprescindível de sua grande criação teórica: o sistema de mercado. Ele está profundamente marcado por um ideal de perfeição divina, baseado em concepções da teologia medieval (seja ela tomista ou agostiniana), pretendendo se constituir, portanto, como um modelo de mercado perfeito.

Assim, analisando um objeto particular, a obra de Adam Smith, pretendemos realizar uma crítica de conotação mais geral ao lluminismo e ao seu ideal de uma "razão secular", como via privilegiada de acesso à "cientificidade"3. Nesse particular, cabe lembrar também que Adam Smith é considerado um autor do assim chamado "Iluminismo escocês", fazendo parte, portanto, da tradição iluminista.

Além disso, apontar a relevância de aspectos religiosos na obra de Adam Smith nos leva a uma questão de ordem metodológica: a imersão na "história de longa duração"

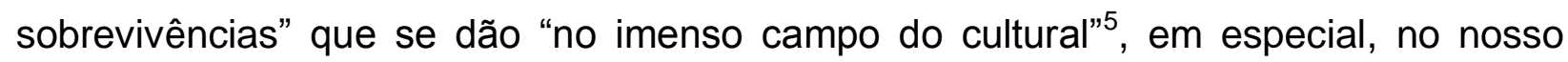
caso, aquelas de caráter religioso.

Do estudo das ideologias políticas ou da história das ideias políticas, campo em que efetivamente se insere a nossa análise, desembocamos no uso cotidiano e atual da expressão "mercado": de nossas afirmações depreende-se que o tal "mercado" (ou "os mercados") de que tanto ouvimos falar nos livros ou nos meios de comunicação em geral, ao invés de ser uma construção absolutamente "moderna", "secular", dotada de "leis gerais" próprias "objetivamente" observáveis, segundo as quais a "eficiência" é

\footnotetext{
${ }^{3}$ Aqui buscamos inspiração na citação do historiador da arte alemão Aby Warburg, feita por Carlo Ginzburg: "Deus está no particular." (Ginzburg, Carlo (1989). "Raízes de um paradigma indiciário". In: Mitos, Emblemas, Sinais: Morfologia e História, São Paulo: Companhia das Letras, p. 143.) Ou seja, a partir de um objeto particular, não abriremos mão de uma crítica de cunho mais geral ao ideal de "cientificidade" e de "razão" próprio do lluminismo, em suma, à ideologia burguesa.

${ }^{4} \mathrm{O}$ conceito remete ao historiador Fernand Braudel e está explicitado em Braudel, Fernand (1990). "A Longa Duração". In: História e Ciências Sociais, Lisboa: Editorial Presença, p. 7-49.

${ }^{5}$ Idem, p. 15.
} 
premiada e a "ineficiência" punida, possui raízes profundas na teologia medieval. Tais raízes podem ser observadas de maneira privilegiada no ideal de perfeição, que dá fundamento ao mercado. Essa é a nossa hipótese geral. E nosso objetivo é rastrear a forma como Adam Smith constrói esse ideal de um mercado perfeito, explanando suas raízes religiosas jamais explícitas.

A crise financeira internacional, por sua vez, pode servir para flagrarmos alguns dos fundamentos desse ideal, já que joga por terra a ideia de um mercado perfeito e autorregulável. Não é à-toa que seu marco foi a quebra do banco estadunidense de investimentos e de análise de "riscos de mercado", Lehman Brothers, na segunda feira, dia 15 de setembro de 2008.

Para termos uma noção mais precisa da severidade dos efeitos dessa crise, o próprio ex-presidente do Banco da Reserva Federal dos EUA (Federal Reserve Bank, Banco Central Estadunidense) Alan Greenspan, que por muito tempo foi chamado de "maestro", devido à importância do seu cargo e ao tempo em que "orquestrou" as diretrizes financeiras da maior economia do mundo ${ }^{6}$, chamou a crise internacional de um "tsunami" no mercado de crédito (credit tsunami) ${ }^{7}$.

Em depoimento para o Congresso dos EUA, a 23 de outubro de 2008, portanto mais de um mês após a quebra do Lehman Brothers, Greenspan afirmou ser a crise muito mais extensa do que jamais poderia ter imaginado, obrigando bancos centrais e governos no mundo todo a tomarem "medidas sem precedentes" (unprecedented measures) ${ }^{8}$.

Cabe lembrar que Greenspan foi um dos maiores defensores da desregulação dos mercados financeiros globais, tendo sido a sua administração do Fed, por muito tempo, considerada como um exemplo de atuação independente a ser seguida por outros bancos centrais. Porém, segundo ele próprio, o maior efeito dessa crise foi ter afetado permanentemente sua "crença" de que os mercados livres, isentos de regulação, são a melhor forma de organizar as economias:

Eu cometi um erro ao presumir que o interesse próprio [self-interest] de organizações, especificamente bancos e outras, era tal que estas eram mais capacitadas para proteger seus próprios acionistas e seus ativos nas firmas. $E$ havia sido a minha experiência, ao trabalhar como um regulador por 18 anos e

\footnotetext{
${ }_{7}^{6}$ Alan Greenspan foi presidente do FED de 1987 até 2006.

7 "Testemunho do Dr. Alan Greenspan" (Testimony of Dr. Alan Greenspan) ao Comitê sobre Omissão Governamental e Reforma do Congresso Americano (Committee of Government Oversight and Reform) a 23 de outubro de 2008, p. 1. (www.oversight.house.gov) Tradução livre do autor.

${ }^{8}$ Idem.
} 
período similar no setor privado, especialmente por 10 anos num grande banco internacional, que os escritórios de empréstimos destas instituições sabiam muito mais sobre os riscos envolvidos e sobre as pessoas a quem eles emprestavam dinheiro, do que eu vislumbrava os melhores reguladores do FED sendo capazes de saber. Então, o problema aqui é algo que parecia ser um edifício bem sólido, e, de fato, um pilar crítico da concorrência de mercado e dos mercados livres realmente colapsou. E penso que isso, como disse, me chocou. ${ }^{9}$

A crise financeira deixou Alan Greenspan, portanto, em "estado de descrença perplexa" (state of shocked disbelief) ${ }^{10}$. Mais adiante, na interlocução com os congressistas, Greenspan chega a admitir verbalmente que ele teria encontrado uma "falha" na sua "ideologia", ou seja, na maneira como ele percebia o "funcionamento do mundo". Além disso, Greenspan aponta também a importância central que a ideologia possui não só para ele, como para todos. Assim, define-a da seguinte forma:

Ideologia (...) é uma moldura conceitual com a qual as pessoas lidam com a realidade. Todos possuem uma. (...) Para existir, precisamos de uma ideologia. (...) A questão é se ela é correta ou não. O que estou dizendo (...) é, 'sim, eu encontrei uma falha', não sei quão significativa ou permanente ela é, mas estou bem angustiado por esse fato. (...) Eu encontrei uma falha no modelo que eu percebia como a estrutura decisiva, que define como o mundo funciona.

Deixemos de lado a mea-culpa de Greenspan e a assunção dos seus equívocos, pois não é exatamente isso que nos interessa. Afinal, não consideramos Greenspan o "maestro" das finanças globais, nem o Fed um modelo de independência a ser seguido, como muitos "especialistas" propuseram. Tampouco estamos interessados em determinar a "correção" ou não de sua ideologia. Nossa preocupação é fazer a análise (social) da ideologia, para, então, realizar sua crítica:

Uma teoria da ideologia deve, por conseguinte, desdobrar-se na explicação da relação entre pensar/agir (estrutura ideológica versus estrutura política) e pensar/sentir (estrutura ideológica versus sistema de inconsciente). Ela deve sugerir como o discurso se relaciona com o sentir e o agir, evidenciando as contradições, os antagonismos, e mostrando como a prática política resolve, na prática, tais contradições. ${ }^{12}$

Destacamos a referência às contradições e aos antagonismos que surgem da análise das relações entre discurso (ideologia) e ação (prática política), enquanto núcleo da proposta de análise social das ideologias. Além disso, uma teoria das

\footnotetext{
${ }^{9}$ Trechos da "transcrição preliminar da audiência" (Preliminary Hearing Transcript) do depoimento de Alan Greenspan ao Comitê sobre Omissão Governamental e Reforma do Congresso Americano (Committee of Government Oversight and Reform) a 23 de outubro de 2008, p. 33/34. (www.oversight.house.gov) Tradução livre e realces negritados do autor.

Ibidem nota 6, p. 2.

${ }^{11}$ Idem nota 8, p. 36/37.

${ }^{12}$ Cerqueira Filho, Gisálio (1988). Análise Social da Ideologia, São Paulo: E.P.U, p. 23.
} 
ideologias deve também mostrar como a prática política concreta "resolve, na prática," as contradições que emergem do cotejamento entre pensar e agir. Dessa forma, lograremos dar eco à afirmação de Jacques Lacan de que "no real não falta nada", despindo-nos de qualquer ideal de "normalidade" (ou o seu contrário, a ideia de "patologia") com relação à realidade social, que acaba por remeter sempre à ideia de que existe um modelo de perfeição/normalidade para como as coisas devem funcionar.

Para levar a cabo essa análise das ideologias, precisamos fazer uso da perspectiva de "longa duração", por dentro da "história das ideias" (políticas), como forma de rastrear as "permanências culturais", que, no tempo presente, seguem incrustadas nas ideias, mesmo naquelas que se apresentam como as mais "modernas", como é o caso do mercado perfeito e autorregulável.

De fato, Greenspan referiu-se a um pilar fundamental do ideal de mercado perfeito criado por Adam Smith: self-interest ou interesse próprio. Sem essa categoria, a suposta estabilidade dos mercados está minada. $E$ foi exatamente isso, que, segundo ele, caiu por terra com a atual crise financeira global.

Ao analisarmos, pois, "A Riqueza das Nações", verificamos que o seu ideal de um mercado perfeito, além do self-interest ("interesse próprio"), mencionado por Alan Greenspan, possui outra premissa fundamental: a invisible hand ("mão invisível"). Ambas estão intimamente relacionadas, pois o indivíduo, segundo Adam Smith, ao perseguir seu self-interest "é levado como que por mão invisível a promover um objetivo que não fazia parte de suas intenções" ${ }^{13}$ : produz também o interesse da sociedade em geral e de uma forma bem mais eficaz do que se tivesse efetivamente a intenção de fazê-lo.

$\mathrm{Na}$ verdade, trata-se da ideia de que existe um componente nuclear, o indivíduo, que, ao perseguir sua "essência" egoísta, seu self-interest, desencadeia um processo de autorregulação ou equilíbrio (promovido por uma suposta "mão-invisível"), que faz com que o "interesse geral" seja também produzido. Essa é a ideia básica que fundamenta a noção de mercado perfeito e é até hoje reproduzida, mesmo com todo o complexo instrumental matemático erigido, sobretudo a partir da economia neoclássica, no fim do século XIX e ao longo do século XX. Marx, por exemplo, chamou tais economistas neoclássicos de "vulgares", devido à sua pretensão de utilizar um arcabouço matemático tão complexo quanto inútil para dar conta das "leis gerais" do

\footnotetext{
${ }^{13}$ Smith. Adam (1983). Riqueza das Nações: Investigação Sobre sua Natureza e suas Causas, São Paulo: Abril Cultural, vol. 1, p. 379/380. Realce negritado do autor.
} 
mercado. Este ímpeto matematizante pouco ou nada mudou da construção básica de Adam Smith. Apenas reproduziu os fundamentos da economia "burguesa", em vez de compreendê-los na sua profundidade para, então, criticá-los.

A própria ideia de indivíduo tem também suas raízes religiosas. Na teologia medieval - tanto a agostiniana quanto a tomista - encontramos uma ideia bastante semelhante, denominada "livre-arbítrio" (libero arbitrio), relacionada a uma discussão muito importante para os teólogos medievais a respeito da existência ou não do "Mal". O livre-arbítrio seria, então, especialmente com Santo Agostinho, uma "dádiva" de Deus, que permite aos homens serem responsáveis pelas suas próprias escolhas, sejam elas "boas" ou "más". Os homens não estão, portanto, condenados ao "pecado"; podem sair dele por livre escolha. Mesmo a percepção humana da "justiça" e da "perfeição" divinas não poderia se efetivar sem o livre-arbítrio; não se poderia elogiar a justiça de Deus, que pune os "pecadores" e recompensa os que agem "bem". O "bom" uso do livre-arbítrio está também intimamente ligado à razão. Sem ela os homens estariam fadados às "inconstâncias" das "paixões", estas sim o verdadeiro caminho do "pecado".

Além disso, não é de hoje que as matemáticas são utilizadas como forma de legitimar um saber com pretensões de ser absoluto, último e indiscutível. Segundo o filósofo José Américo Motta Pessanha, importante organizador da coleção "Os Pensadores" no Brasil, tal ímpeto vem desde os pitagóricos e possui também raízes profundamente religiosas.

É preciso não esquecer: o ideal de um discurso científico inteiramente convertido à limpidez e ao rigor das tessituras lógico-matemáticas possui também raízes religiosas; ganhou força e apaixonou por séculos boa parte do moderno pensamento ocidental justamente por constituir um sonho de iluminação total do conhecimento, da linguagem, da vida; pode persistir ainda hoje e empolgar os espíritos - mas com o apelo e a sedução das utopias. $O$ ideal permanece ideal - e o sonho, sonho. ${ }^{14}$

E não foi justamente a "economia", as "ciências econômicas", agora já distante de sua origem enquanto economia política, que se transformou numa "econométrica dos mercados", numa economics, abraçando profundamente o instrumental matemáticoestatístico na construção de "modelos" para se aproximar de um ideal de cientificidade (perfeita)? Pois bem, esse apelo matemático, para além da construção básica de Adam

\footnotetext{
${ }^{14}$ Motta Pessanha, José Américo (1981). "Razão Humana, Razão Divina - os limites internos e externos do formalismo". In: Revista Filosófica Brasileira, Rio de Janeiro, IFCS-UFRJ, vol. 1 no.0, p. 19. Realces negritados do autor.
} 
Smith, tem também suas raízes religiosas, que a "modernidade" absorveu profundamente na assim chamada "Revolução Científica Moderna", que teve na Física Newtoniana seu modelo mais admirado.

O resultado desse "sonho de iluminação total do saber", sintetizado, pois, no ideal de um saber que se pretende indiscutível e necessário - um saber, em uma palavra, "perfeito" -, apoiado na linguagem matemática, foi uma completa matematização do conhecimento e da própria vida; da astronomia à música, da medicina à política, etc. Nesse sentido, a matematização da economia, com os neoclássicos, constitui apenas um exemplo de um movimento mais amplo em busca de um saber "perfeito".

$\mathrm{Na}$ continuidade de sua argumentação sobre as raízes religiosas da matematização do conhecimento, José Américo convoca Bachelard:

Se quisermos retraçar a história do determinismo, seria necessário retomar toda a história da Astronomia. É das profundezas dos céus que se delineia o Objetivo puro que corresponde a um Visual puro. É sobre o movimento regular dos astros que se regra o Destino (...) Ela [a astronomia] ensina o homem a lei física nos seus caracteres de objetividade e de determinismo absoluto. Sem essa lição de matemática astronômica, a geometria e o número não estariam provavelmente associados ao pensamento experimental; o fenômeno terrestre tem uma diversidade e uma mobilidade imediatas demasiado manifestas para que se possa encontrar nelas, sem preparação psicológica, uma doutrina da Objetividade e do Determinismo. O Determinismo desceu do Céu sobre a Terra. $^{15}$

Impossível não recordar, a partir da citação de Bachelard, das palavras de Karl Marx e Friedrich Engels, na "Ideologia Alemã", possivelmente os maiores críticos da economia política burguesa. Neste texto, agora clássico, seus autores, ao proporem a crítica do idealismo hegeliano alemão, afirmam que este "desce do céu sobre a terra"16. $\mathrm{Na}$ verdade, trata-se de uma crítica, que, apesar de seu caráter aparentemente específico - referindo-se ao pensamento alemão hegeliano - possui um caráter geral de crítica ao pensamento burguês.

Marx e Engels acertaram em cheio e, com eles, também Bachelard, pois é exatamente isso que Adam Smith realiza em sua obra "A Riqueza das Nações": inspirado nos valores da Revolução Científica Moderna e na Física Newtoniana, constrói um ideal de mercado perfeito, que igualmente "desce do céu sobre a terra".

O racionalismo moderno, em especial com Descartes, ressuscita a ideia de Deus na mente dos Homens. É a razão (divina), através da linguagem matemática (como

\footnotetext{
${ }^{15}$ Ibidem, p. 20. Realces negritados do autor.

16 "(...) desciende del cielo sobre la tierra (...)". Marx, Carlos e Engels, Federico (1973). La Ideologia Alemana, Buenos Aires: Ediciones Pueblos Unidos, p. 26.
} 
padrão de cientificidade), que permite aos homens atingir um conhecimento necessário e universal, que subjuga a mente. A razão individual - o "cogito" - nos permite ler a ordem na própria mente, que se revela a partir das idéias claras e distintas dispostas por Deus em nosso "cogito". Nesse sentido, para Descartes, "a reta razão é um reencontro da razão humana com a Razão Divina; conhece-se corretamente conhecendo-se em Deus e por Deus"17.

Já em Thomas Hobbes, bem a gosto da tradição anglo-saxã iniciada com Francis Bacon, a "razão" serve aos homens para que estes possam ler a "ordem divina" na natureza, cuja definição clássica é: "arte mediante a qual Deus fez e governa o mundo"18. Então, é a "razão individual" que permite a Hobbes visualizar os contornos da ordem política. Mas é um sentimento, uma "paixão", o medo da morte violenta, que impele os homens a erigir tal sistema político "artificial". Nesse aspecto reside talvez uma das grandes inovações do pensamento de Thomas Hobbes, e onde este se faz efetivamente "moderno": trata-se da idéia de que uma "paixão" ou um "sentimento" pode contribuir para controlar outras paixões mais "perigosas", produzindo até mesmo os incentivos necessários para a construção de uma ordem política "racional". De resto, a importância do medo na obra de Thomas Hobbes em suas interrelações com a religiosidade e a submissão foi abordada pelo historiador Carlo Ginzburg em conferência inédita proferida na Universidade Federal Fluminense (UFF) e organizada pela professora Gizlene Neder do Laboratório Cidade e Poder (LCP/UFF) ${ }^{19}$.

No fundo, trata-se de uma ideia absolutamente autorizada e vislumbrada pelo pensamento religioso - a de que um determinado "vício" ou "paixão" de origem (do ser humano) pode gerar benefícios, pode servir para o "Bem", pode auxiliar no combate de outras "paixões" destrutivas e rebeldes. O rastreamento dessa ideia é feito de forma competente por Albert O. Hirschman em seu livro "As paixões e os interesses". Como observa o próprio, Adam Smith constitui, nesta trajetória, um ponto culminante de uma ideia que já vinha há muito rondando o pensamento europeu, mas que este foi capaz

\footnotetext{
${ }_{17}^{17}$ Motta Pessanha, José Américo (1981). Op. Cit., p. 24.

${ }^{18}$ Hobbes, Thomas (1974). Leviatã ou Matéria, Forma e Poder de um Estado Eclesiástico e Civil, São Paulo: Abril Cultural, p. 9.

${ }_{19}$ Ginzburg, Carlo (2006). Medo, Reverência e Terror - Reler Hobbes Hoje. Conferência realizada em 18/09/2006, sob os auspícios do Laboratório Cidade e Poder do Departamento de História da Universidade Federal Fluminense (LCP/UFF), Niterói, Brasil, por iniciativa da professora Gizlene Neder. Tradução de Luiz Fernando Franco.
} 
de tornar "aceitável e convincente" ${ }^{20}$, construindo sobre ela todo um "sistema" - o de mercado.

Segundo Hirschman, essa ideia tem sua origem também na teologia medieval. Santo Agostinho, por exemplo, já vislumbrava a possibilidade de que um "vício" poderia reprimir outro. Acrescentamos, contudo, que essa possibilidade não é vislumbrada apenas por Santo Agostinho, estando presente também em São Tomás de Aquino, especialmente quando este afirma que "Deus é tão-poderoso que pode até fazer o bem a partir do mal”21.

Hirschman aponta, ao longo de seu texto, como essa ideia, de raiz religiosa, se espalha e encontra fortes adeptos, especialmente com os filósofos moralistas do século $\mathrm{XVIII}$, tanto franceses quanto anglo-saxões. Estes a levam às últimas conseqüências, construindo amplos sistemas filosóficos "morais" sobre ela.

É o caso, por exemplo, de David Hume, amigo pessoal de Adam Smith e cujas ideias muito o influenciaram. Apesar de afirmar que "a razão é, ou deveria ser, apenas a escrava das paixões" ${ }^{22}$, Hume destaca em suas obras uma paixão muito bem delimitada: "A avareza, ou o desejo do ganho", que, segundo ele "é uma paixão universal que opera em todas as épocas, em todos os lugares, e sobre todas as pessoas" ${ }^{23}$. Antes de ser um pensador cético, devemos ter em conta, pois, que David Hume é um pensador burguês.

Essa idéia do "amor pelo ganho pessoal", enquanto uma espécie de "essência humana", será reutilizada por Smith para a construção do sistema de mercado perfeito, baseado, portanto, numa suposta concepção de um "homem natural", cuja "essência" seria, na terminologia de Smith, o self-interest.

De certa forma, temos a reedição da ideia defendida pelo pensador francês Blaise Pascal, de caráter tomista, de que as paixões devem ser controladas, com a diferença de que isso só seria possível por meio de outra "paixão", o tal self-interest. Nesse particular, é interessante observar a menção que Hirschman faz aos jansenistas em nota:

A idéia de que uma sociedade unida pelo amor-próprio em vez de pela caridade possa ser viável apesar de pecaminosa é encontrada entre um

\footnotetext{
${ }^{20}$ Hirschman, Albert O. (2002). As Paixões e os Interesses, Rio de Janeiro: Record, p. 40.

${ }^{21}$ Marcondes, Danilo (2007). Textos Básicos de Ética - de Platão a Foucault. Rio de Janeiro: Jorge Zahar, p. 64

${ }^{22}$ Idem, p. 84.

${ }^{23}$ Hirschman, Albert O. (2002). Op. cit., p. 75. Realce negritado do autor.
} 
número de proeminentes jansenistas contemporâneos de Pascal, tais como Nicole e Domat.

Isso é compreensível, já que a ideia de que "paixões" podem reprimir outras "paixões" não anula o pensamento de que, no fundo, as paixões devem ser reprimidas, nem que por outras paixões, digamos, menos "prejudiciais".

A mesma crítica que Marx e Engels fizeram à ideologia em geral e à alemã em particular fazemos à economia burguesa em geral e à de Adam Smith em particular: Esta apenas substitui o dogma moderno da "razão" por outra hipotética "essência humana", igualmente dogmática - o self-interest. No fundo, (seja a razão, seja o selfinterest) ambos têm como "missão" controlar as "paixões" humanas, produzindo "docilidade". Em suma, controlar os afetos, considerados como o verdadeiro "perigo", o grande "vício" de origem dos homens. Um projeto que apenas substitui a fé/crença em Deus, como sugere Blaise Pascal, pela crença no ímpeto natural do homem pelo enriquecimento pessoal (self-interest).

Justamente sobre essa "essência", posteriormente, a economia neoclássica e, mais recentemente, a própria ciência política (não à-toa, especialmente, a anglo-saxã) erigirá um pomposo edifício formal-matemático. Ao mesmo tempo em que fará do assim chamado "individualismo metodológico" premissa básica de seus modelos matemáticos, obscurecerá ainda mais suas próprias raízes religiosas e dogmáticas. Como se o ser humano e os afetos humanos se resumissem a determinados "interesses"...

A essa "essência" do homem, que Adam Smith denominou self-interest, este acrescenta a mão-invisível, que garante a "ordem" do mercado. A referência a uma "mão-invisível” tampouco se dá à-toa: É a mão-invisível de Deus, que regula o mercado, garantindo seu equilíbrio. Em última instância, ela realiza a tarefa divina de atribuir a cada um o seu devido lugar, nessa ordem geral criada e regulada por Deus. A passagem a seguir, de Santo Agostinho, ajudar a elucidar as ligações da mão-invisível com os céus:

De fato, não pode haver nenhuma realidade que não proceda de Deus, e em todas as coisas que perceberes haver medida, número, ordem, podes atribuílas sem hesitação a Ele. (...) Aquele que cai por responsabilidade própria, pode também voltar a erguer-se da mesma forma. Isso acontece porque do céu Deus nos estende a Sua mão direita, que é Cristo. Devemos pegá-la com fé 
firme, esperando essa ajuda com toda a confiança e esperança, desejando-a com ardoroso amor. ${ }^{24}$

Santo Agostinho apresenta um princípio fundamental para a construção do saber "científico" na modernidade: a existência de medida, número e ordem. Esse princípio está fundamentado em Deus, cuja perfeição os modernos passaram a ler na sua "criação", ou seja, na natureza. Uma natureza criada por Deus e, por isso mesmo, perfeita, possuindo, portanto, “medida, número e ordem” própria.

Apesar de ser apresentada como dotada de "objetividade" e fundamentos "rigorosos", a tal "ciência moderna" está completamente fundamentada em noções religiosas, com forte pregnância da teologia medieval. Assenta-se, pois, em noções e conceitos baseados especialmente num ideal de perfeição divina e na doutrina do criacionismo.

Segundo Valter Duarte, cientista político e estudioso da economia política, o ideal de equilíbrio, fundamental para o entendimento da "ordem" do mercado, deita raízes numa obra de grande repercussão à sua época na Inglaterra: Trata-se do livro The Commonwealth of Oceana, de James Harrington, publicado na Inglaterra em 1656. Duarte argumenta que, apesar da pequena importância atribuída a Harrington na literatura política "especializada", talvez devido ao próprio caráter utópico de sua obra, cujas instituições meticulosamente sistematizadas jamais foram "concretamente" realizadas, o princípio de equilíbrio ali apresentado teve grandes desdobramentos no plano da ideias. Sua influência se estende tanto à Física Newtoniana, quanto à Economia Política de Adam Smith ${ }^{25}$ :

Com efeito, este veio a ser o reaparecimento do antigo ideal de equilíbrio de Harrington em torno do qual em 1656 esse autor pensara como devia ser realizada a ordem geral da 'Commonwealth'. Mas desta vez, embora restrito ao sistema de trocas e à formação de 'stocks', o novo equilíbrio idealizado teria fundamento divino e não teria a necessidade de que fosse pensada a criação de instituições para realizá-lo. O 'mercado' não dependeria de leis civis, pois, como mais tarde economistas inspirados na construção básica de Adam Smith diriam, ele teria as suas próprias 'leis'. E de fato, em sua construção lógica de base, o sistema de 'mercado' em si conteria a sua própria ordem. Em tal ordem, o equilíbrio, o qual se realizaria sem que se precisasse de leis jurídicas para ensinar os homens egoístas a obedecerem à natureza humana, estaria nas suas relações necessárias - as suas trocas de mercadorias por mercadorias - no funcionamento global da oferta e da procura dessas

\footnotetext{
${ }^{24}$ Marcondes, Danilo (2007). Op. cit., p. 57. Realces negritados do autor.

25 Duarte, Valter (2007). "Saber Matemático e Saber Político". In: Revista Dissertar - Revista da Associação de Docentes da Estácio de Sá, Rio de Janeiro, v. 10, p. 45-50.
} 
mercadorias e também no uso dos 'stocks', a riqueza geral das nações que os proprietários privados teriam acumulado. ${ }^{26}$

O problema é que, para construir esse ideal de perfeição, Adam Smith precisa afastar, a todo custo, qualquer traço que remetesse à "política" no mercado. Não apenas por não gostar dela, mas justamente devido a uma conformidade com certos "valores religiosos", certas "permanências de longa duração" evidenciadas no seu ideal de um mercado perfeito. Essas "permanências" de cunho religioso encontram-se profundamente arraigadas aos "novos" valores "científicos" da "civilização" (anglosaxã), que fundamentaram os pensamentos nem sempre convergentes de Bacon, Hobbes, Harrington, Locke, Newton, Hume e Smith, desembocando na construção das "instituições políticas liberais", que hoje em dia se convencionou chamar (equivocadamente) pelo nome de "democracia". Tratou-se, na verdade, historicamente, da afirmação político-ideológica da Commonwealth. Ou seja, da comunidade de proprietários privados ingleses, que tinha na sua "riqueza comum" (commonwealth) o ponto de convergência para a construção de uma "ordem" (política), que salvaguardasse as suas próprias propriedades, Ihes proporcionando a segurança para a circulação livre e a multiplicação das mesmas.

A construção dessa "ordem" dependeu de um processo de descoberta (a um só tempo político e religioso) de Deus na natureza. Daí o forte desenvolvimento do ceticismo e sua adesão ao "fenômeno" no pensamento anglo-saxão. Trata-se de uma marca do pensamento burguês, prenhe de "permanências" religiosas: a leitura da ordem divina na natureza. É por isso, que Adam Smith quer a todo o custo afastar a política de "seu mercado": devido à absorção desses "valores" banhados em noções teológicas, cujo indício é ideal de perfeição.

Segundo o antropólogo francês Louis Dumont, a própria existência de um domínio econômico autônomo, dependeu de uma exigência "lógica" de afastamento absoluto da política.

Quanto à sua própria gênese (...) o traço distintivo do domínio econômico repousa sobre o postulado de uma coerência interna orientada para o bem do homem, o que é fácil de compreender dadas as circunstâncias: a emancipação do político requeria a suposição de coerência interna, pois de outra forma a ordem teria de ser introduzida de fora. Mas isto não é tudo: se fosse

${ }^{26}$ Duarte, Valter (1997). "Sistema de Mercado': O Ideal Político e Religioso de Adam Smith." In: Economia: Obstáculo Epistemológico, Op. cit., p. 376. 
demonstrado que tal coerência interna teria efeitos perniciosos, o político ou o homem de Estado encontrariam, novamente, ocasião para intervirem. ${ }^{27}$

Não é à-toa, pois, que Adam Smith promove duras críticas àquilo que chama de "sistema mercantil", enquanto faz apenas algumas restrições ao "sistema agrícola" ou fisiocrata, afirmando ser este último "o mais aproximado da verdade que jamais se publicou em matéria de Economia Política" ${ }^{28}$. Isso porque os mercantilistas aceitavam o fundamento político do dinheiro. Para eles, riqueza seria dinheiro, seu meio de obtenção seria o comércio exterior e o seu agente, o governo ${ }^{29}$.

Duarte, por exemplo, chega a afirmar que Adam Smith é radical neste particular, pois argumenta em favor de uma ordem "natural" para a vida dos homens, que se opõe a qualquer ordem político-institucional, fosse ela absolutista ou liberal. Smith nem mesmo aceitava o comando do mercado pelo governo civil $^{30}$.

É por isso - devido ao ideal de perfeição que se transforma em idealização - que Adam Smith precisa promover o esforço teórico de "despolitizar" o dinheiro, argumentando que este não é riqueza, mas um mero "meio de troca" e "reserva de valor". Afinal, o mercado perfeito não poderia ter sua "riqueza", nem mesmo sua "medida de valor" definida pelo poder político, como aceitavam os mercantilistas. Era apenas uma exigência "lógica" dentro dos valores religiosos da Commonwealth. As ligações do poder político precisavam, pois, ser ocultadas numa outra concepção do que é a riqueza e da própria função do dinheiro. A política não poderia ter lugar aí. Segundo Valter Duarte, Smith empreende então, o esforço de "civilizar" o dinheiro de acordo com os valores da Commonwealth, afastando-o da política:

Em rigor, o mercado só teria existência própria, absoluta, se o dinheiro não tivesse nada daquilo que era a sua efetiva realidade política. $O$ dinheiro com todo o seu real poder de comando era o maior obstáculo para a idéia da existência de uma ordem natural da produção ao consumo que fosse autosuficiente e soberana diante de todas as outras possíveis ordens sociais. Por isso, mas admitindo-se que Adam Smith estivesse motivado por um ideal naturalista, o 'mercado', a imagem que sob a influência dos valores da chamada Revolução Científica Moderna seria pensada depois como sendo a natural e autêntica realidade 'econômica', só poderia ser sustentada como

${ }^{27}$ Dumont, Louis (2000). Homo Aequalis: Gênese e Plenitude da Ideologia Econômica, Bauru, SP: EDUSC, p.53. Realces negritados do autor.

${ }^{28}$ Smith, Adam (1983). Op. cit., vol. 2, p. 140.

${ }^{29}$ Duarte, Valter (1997). "Sistema de Mercado': O Ideal Político e Religioso de Adam Smith." In: Economia: Obstáculo Epistemológico, Op. cit., p. 372.

${ }^{30}$ Idem, p. 366. 
imagem argumentativa se a sua organização racional pudesse ser radicalmente negadora do dinheiro. ${ }^{31}$

Mercado perfeito, portanto, justamente porque livre da "política", agora "recalcada", e, por isso, aparentemente sem necessidade de intervenção da "mão visível" do príncipe. O mercado perfeito constrói-se tendo em vista não mais os objetivos de centralização do poder em torno do príncipe, mas em torno dos proprietários privados ingleses. Mas esse ideal não passa de um "sonho", um "sonho de iluminação total", como diria José Américo. Afinal, sabemos que a perfeição é algo que não existe para além do imaginário e dos sentimentos.

A crítica tradicional coloca-se na direção de demonstrar historicamente o quanto de poder político foi necessário para que a tal "mão-invisível" do mercado pudesse funcionar com "perfeição". Estamos absolutamente de acordo com essa crítica, contudo nosso objetivo é fazer a crítica no plano da ideologia.

Nesse plano, portanto, o mercado perfeito se encontra com o príncipe perfeito justamente no ideal de perfeição, herdado da teologia medieval e fundamentado em "valores religiosos". No plano das "práticas políticas concretas", nem mesmo Adam Smith pôde negar a necessidade de intervenção política. Contudo, não exatamente da política como "arte" de Maquiavel, mas da política como "missão" de São Tomás de Aquino. Missão de salvar e salvaguardar o mercado perfeito, garantindo sua segurança e "certas obras e instituições públicas":

Segundo o sistema de liberdade natural [mercado perfeito], ao soberano
cabem apenas três deveres, por certo, de grande relevância, mas simples e
inteligíveis ao entendimento comum: primeiro, o dever de proteger a sociedade
contra a violência e a invasão de outros países independentes; segundo, o
dever de proteger, na medida do possível, cada membro da sociedade contra
a injustiça e a opressão de qualquer outro membro da mesma, ou seja, o
dever de implantar uma administração judicial exata; e terceiro, o dever de
criar e manter certas obras e instituições públicas que jamais algum
indivíduo ou um pequeno contingente de indivíduos poderão ter interesse em
criar e manter, já que o lucro jamais poderia compensar o gasto de um
indivíduo ou de um pequeno contingente de indivíduos, embora muitas vezes
ele possa até compensar em maior grau o gasto de uma grande sociedade. ${ }^{32}$

Quem disse que o mercado se constrói sobre a luta político-ideológica e que as funções que realiza não têm fundo político? Sabemos que a tal segurança se refere aos agentes detentores e multiplicadores da "riqueza" na Commonwealth: os

\footnotetext{
${ }^{31}$ Ibidem, p. 385.

${ }^{32}$ Smith, Adam (1983). Op. cit., vol. 2, p. 147. Realces negritados do autor.
} 
proprietários privados. E a tal "liberdade natural", se refere às liberdades desses mesmos proprietários de dispor, como bem entender, de suas riquezas individuais.

Ambos - tanto o príncipe perfeito quanto o mercado perfeito - atribuem "a cada um o que the é devido", de acordo com os princípios da justiça (divina). Ambos são soberanos, tais quais deuses na terra. O mercado perfeito premia o "eficiente" e pune o "ineficiente"; o príncipe perfeito protege o "justo" e pune o "injusto", e Deus absolve o "bom" e pune o "mal".

\section{Bibliografia}

BORRMANN, R. G. (2009) Tal Mercado, Tal Príncipe: o paradigma da perfeição na economia política burguesa, Dissertação de mestrado orientada pelo Prof. Titular de Teoria Política Dr. Gisálio Cerqueira Filho. Programa de Pós-Graduação em Ciência Política, UFF, Niterói.

Braudel, F. (1990). "A Longa Duração". In: História e Ciências Sociais, Lisboa: Editorial Presença, p. 7-39.

Cerqueira Filho, G. (1988) Análise Social da Ideologia, São Paulo: E.P.U.

Duarte, V. (1997). "Sistema de Mercado': O Ideal Político e Religioso de Adam Smith. In: Economia: Obstáculo Epistemológico, Tese de Doutorado. Instituto de Economia Industrial, UFRJ, Rio de Janeiro, p. 359-391.

Duarte, V. (2007). "Saber Matemático e Saber Político". In: Revista Dissertar - Revista da Associação de Docentes da Estácio de Sá, Rio de Janeiro, v. 10, p. 45-50.

Dumont, L. (2000). Homo Aequalis: Gênese e Plenitude da Ideologia Econômica, Bauru, SP: EDUSC.

Ginzburg, C. (2006). Medo, Reverência e Terror - Reler Hobbes Hoje, Conferência realizada em 18/09/2006, sob os auspícios do Laboratório Cidade e Poder do Departamento de História da Universidade Federal Fluminense (LCP/UFF), Niterói, Brasil, por iniciativa da professora Gizlene Neder. Tradução de Luiz Fernando Franco.

Ginzburg, C. (1989). "Raízes de um paradigma indiciário". In: Mitos, Emblemas, Sinais: Morfologia e História, São Paulo: Companhia das Letras, p. 143-179.

Hirschman, A. O. (2002). As Paixões e os Interesses, Rio de Janeiro: Record.

Hobbes, T. (1974). Leviatã ou Matéria, Forma e Poder de um Estado Eclesiástico e Civil, São Paulo: Abril Cultural.

Marcondes, D. (2007). Textos Básicos de Ética - de Platão a Foucault, Rio de Janeiro: Jorge Zahar. 
Marx, C. e Engels, F. (1973). La Ideologia Alemana, Buenos Aires: Ediciones Pueblos Unidos.

Motta Pessanha, J. A. (1981). "Razão Humana, Razão Divina - os limites internos e externos do formalismo". In: Revista Filosófica Brasileira. Rio de Janeiro, IFCS-UFRJ, vol. 1 no. 0, p. 19-27.

Smith. A. (1983). Riqueza das Nações: Investigação Sobre sua Natureza e suas Causas, São Paulo: Abril Cultural.

\section{Documentos:}

"Transcrição Preliminar da Audiência" (Preliminary Hearing Transcript) do depoimento de Alan Greenspan ao Comitê sobre Omissão Governamental e Reforma do Congresso Americano (Committee of Government Oversight and Reform) a 23 de outubro de 2008, p. 33/34. (www.oversight.house.gov).

"Testemunho do Dr. Alan Greenspan" (Testimony of Dr. Alan Greenspan) ao Comitê sobre Omissão Governamental e Reforma do Congresso Americano (Committee of Government Oversight and Reform) a 23 de outubro de 2008, p.2. (www.oversight.house.gov). 